\title{
De lange arm van de bijstand (II)
}

\author{
mr. F.M.H. Hoens
}

Kennis van de bijstand en de Participatiewet (PW) makkt onderdeel uit van de gereedschapskist van de estate planner. Bij menig cliënt leeft immers de wens om (aan erfgenamen na te laten) vermogen buiten de reikwijdte van de bijstand te houden. Dat dit in de regel niet bereikt wordt door te werken met testamentaire bewinden en/of niet-opeisbaarheidsclausules, is genoegzaam bekend (zie Bauduin, 'Testamentair bewind, “bijstandproof'?', TE 2014/04). Ook uit een uitspraak van de Centrale Raad van Beroep (26 juli 2016, ECLI:NL:CRVB:2016:2866) blijkt weer eens dat de lat bij 'bijstandproof-handelen' hoog lijkt te liggen.

Kort en sterk vereenvoudigd enkele feiten. X ontvangt sinds 1998 een bijstandsuitkering. $X$ is enig bestuurslid van een stichting. Het vermogen van die stichting bestaat onder meer uit een in Suriname gelegen perceel grond met daarop een vrijstaande woning.

Uit de feiten die een onderzoek door de sociale recherche oplevert, concludeert het college van burgemeester en wethouders van de bijstand verstrekkende gemeente dat:

' $[\mathrm{X}]$ in strijd met de op hem rustende inlichtingenverplichting niet heeft gemeld dat hij vanaf 7 maart 2011 over vermogen boven de voor hem van toepassing zijnde vermogensgrens beschikt, bestaande uit een perceel grond en de daarop staande woning in Suriname, zodat geen recht op bijstand bestond. $[\mathrm{X}]$ heeft hierdoor ten onrechte bijstand ontvangen.' (Curs. en toev. FH)

Gezien het feit dat niet X, maar een stichting rechthebbende is tot de woning, een op het eerste gezicht opmerkelijke stelling. Het bezwaar van $\mathrm{X}$ tegen het (terugvorderings)besluit van het college wordt afgewezen en de rechtbank verklaart het beroep tegen dit besluit ongegrond. De zaak belandt bij de Centrale Raad van Beroep:

'4.4.2. Uit het onderzoek [...] blijkt dat [X] enig bestuurslid is van de Stichting en in die hoedanigheid het vermogen van de Stichting beheert. Vaststaat verder dat het vermogen van de Stichting bestaat uit een perceel grond met een daarop staande woning.

Uit de notariële akte van de verkoop van de woning van 7 maart 2011 blijkt dat $[\mathrm{X}]$ de woning als mede-eigenaar aan de Stichting heeft verkocht. De vader en broer van $[\mathrm{X}]$ waren ten tijde van de verkoop eveneens mede-eigenaar van de woning. Dit betekent dat het vermogen van de Stichting mede is gevormd door het privé vermogen van $[\mathrm{X}]$.' (Curs. en toev. $\mathrm{FH}$ )

Uit de verdere overwegingen van de Raad blijkt dat X hiertegen aanvoert dat hij niet $\mathrm{kan} /$ kon beschikken over de woning, aangezien de stichting is opgericht ter uitvoering van de uiterste wilsbeschikking van zijn ouders, inhoudende (samengevat) dat de woning niet zal overgaan op anderen. De uitspraak zwijgt over aard en inhoud van de 
uiterste wilsbeschikking, maar met wat goede wil zou hier een last ontwaard kunnen worden. Wat hier ook van zij, het verweer van X slaagt niet omdat:

'Uit de notariële akte van oprichting van de Stichting van 10 december 2010 blijkt niet dat de Stichting ter uitvoering van deze wilsbeschikking is opgericht. De Stichting heeft namelijk als doel het verkrijgen, vervreemden, beheren en/of besturen van roerende en/of onroerende zaken, effecten en vermogens of vermogensbestanddelen. Dit betekent dat $[\mathrm{X}]$ als enig bestuurslid van de Stichting niet alleen bevoegd was de woning aan te kopen, maar ook bevoegd is de woning te beheren en te vervreemden.' (Curs. en toev. FH)

En:

'4.4.3. Gelet op 4.4.1 en 4.4.2 heeft het college zich terecht op het standpunt gesteld dat sprake is van een zodanige verstrengeling van het vermogen van de Stichting en het vermogen van $[\mathrm{X}]$ dat $[\mathrm{X}]$ geacht wordt redelijkerwijs te kunnen beschikken over de woning. In een dergelijke situatie ligt het op de weg van $[\mathrm{X}]$ om het tegendeel aannemelijk te maken. [...]' (Curs. en toev. FH)

Daarmee is het bijstandsnet rond $\mathrm{X}$ gesloten. Vermogen waarover men beschikt of redelijkerwijs kan beschikken behoort tot de middelen van artikel 31 lid $1 \mathrm{PW}$. De inlichtingenplicht van artikel $\underline{17} \mathrm{PW}$ verplicht de bijstandsgerechtigde $\mathrm{X}$ om op verzoek of onverwijld uit eigen beweging mededeling te doen van feiten en omstandigheden die van invloed kunnen zijn op het recht op bijstand. Zonder twijfel valt het (redelijkerwijs) kunnen beschikken over vermogen onder de inlichtingenplicht.

Voor de planningspraktijk is in ieder geval duidelijk dat het 'tussenschuiven' van een rechtspersoon ter omzeiling van bijstandsgevolgen van vermogensbezit geen gegarandeerd succes oplevert. Onduidelijk is of en in hoeverre een andere samenstelling van het bestuur van de stichting en/of een mindere 'verstrengeling' tot een andere uitkomst zouden hebben geleid.

Tot volgende week!

mr. F.M.H. Hoens 